\title{
The Reefer Industry in a Historical Context
}

This book follows the independent reefer operators from their birth until the present day. The following macro level description serves as a background and general context to the corporate narratives that we will present in the rest of the book. The independent reefer operators are part of the maritime link in the cold chain, which in turn is connected to the development of agriculture, international trade, technological and political developments. To fully describe this would be beyond the scope of this book. Instead, we sketch some basic contours which are relevant to the understanding of the development of the independent reefer operators.

Also, the discursive construction of the reefer, which we explained in the introduction, complicates the limited historical data that is available. For example, reefer tonnage is sometimes included with refrigerated liner capacity, and sometimes not. Smaller reefer vessels are frequently excluded from data sets and processes of inclusion and exclusion vary and are usually not explicit. Therefore, the description below is not aimed at giving a quantitative overview of the development of the industry, even though some data is used for illustrative purposes.

\section{The Beginnings: Meat, Bananas and Fish}

The refrigerated shipping market was born in the late nineteenth century, initially with the meat trade. This development, as well as the banana and fish trades that followed, will be descibed below. The timing of the birth of the refrigerated trades fits well into the development of the shipping industry and the emerging systems of international trade. From 1842 to 1887 , the sea trade of general cargo grew by $4.2 \%$ per year. The advent of steamships made long-haul trades viable for a greater range of cargo than before. Previous trades with luxuries like spices, silk and sugar could now be supplemented with less valuable cargoes. One outcome of this was that colonial possessions that didn't produce these luxuries could now generate more value since shipping costs were reduced and the cargo spent less time at sea. Without the transformation of the shipping industry from sail to steam, from wooden to iron hulls, using screw propellers, and a deep-sea communications network these international trades 
could not have emerged. At the same time, the prospects of international trade fuelled such shipping innovations.

Towards the late 1800 s there was a constant pressure to make the long-haul trade more effective with more efficient engines (reducing the fuel consumption by $75 \%$ per ton mile from 1855 to $1915^{1}$ ), and to increase the speed of shipments further. The passenger traffic and mail contributed to the commercial pressures to increase the speed of shipping ${ }^{2}$. This increased pressure for speed was also a prerequisite for carrying sensitive reefer cargoes.

The reefer trades are thus a natural part of the more general trends of industrialization, the development of long-haul international trade, and the largescale technological transformation of the shipping industry. Given the sensitive nature of the reefer cargo, the emergence of such international reefer trades was also dependent on the development of refrigeration technology, although early attempts involved the use of natural ice.

\subsection{Meat}

The early refrigerated shipping market was mainly concerned with transporting frozen meat to the growing and increasingly affluent British population. While local British supply was scarce, meat was abundant in the British Dominions of Australia and New Zealand, and also in Argentina and elsewhere in the Americas ${ }^{3}$. Early, canned meat was imported and also chilled meat from North America using natural ice ${ }^{4}$. But canned meat wasn't able to satisfy the market and the North American exports declined in the late 19th century. To be able to secure long-distance imports, there was a need for refrigerated vessels, or rather, freezers. Meat, compared to other refrigerated cargo that would appear later, was, in retrospect, a quite simple cargo to transport. It basically needed to be kept below freezing point.

Experiments with emerging refrigeration technologies were proceeding and the market opportunity prompted their refinement. The first freezing works were built in Sydney in $1861^{5}$ and soon the technology was applied to shipping. Initial Australian attempts to ship meat failed but were soon followed by

1 Stopford, M. 2009. Maritime Economics, New York: Routledge, p. 26.

2 Stopford 2009, p. 23.

3 The early history of British meat imports is described in Oddy, D.J. 2007. The Growth of Britain's Refrigerated Meat Trade 1880-1939, The Mariner's Mirror, 93: 269-280.

4 Perren, R. 2006. Taste, Trade and Technology: The Development of the International Meat Industry since 1840, Aldershot: Ashgate, p. 47-49.

5 The history of early Australian meat exports is based on Pearson, M. and Lennon, J. Pastoral Australia: Fortunes, Failures and Hard Yakka: a Historical Overview 1788-1967, Collingwood: CsIro Publishing, pp. 68-70. 


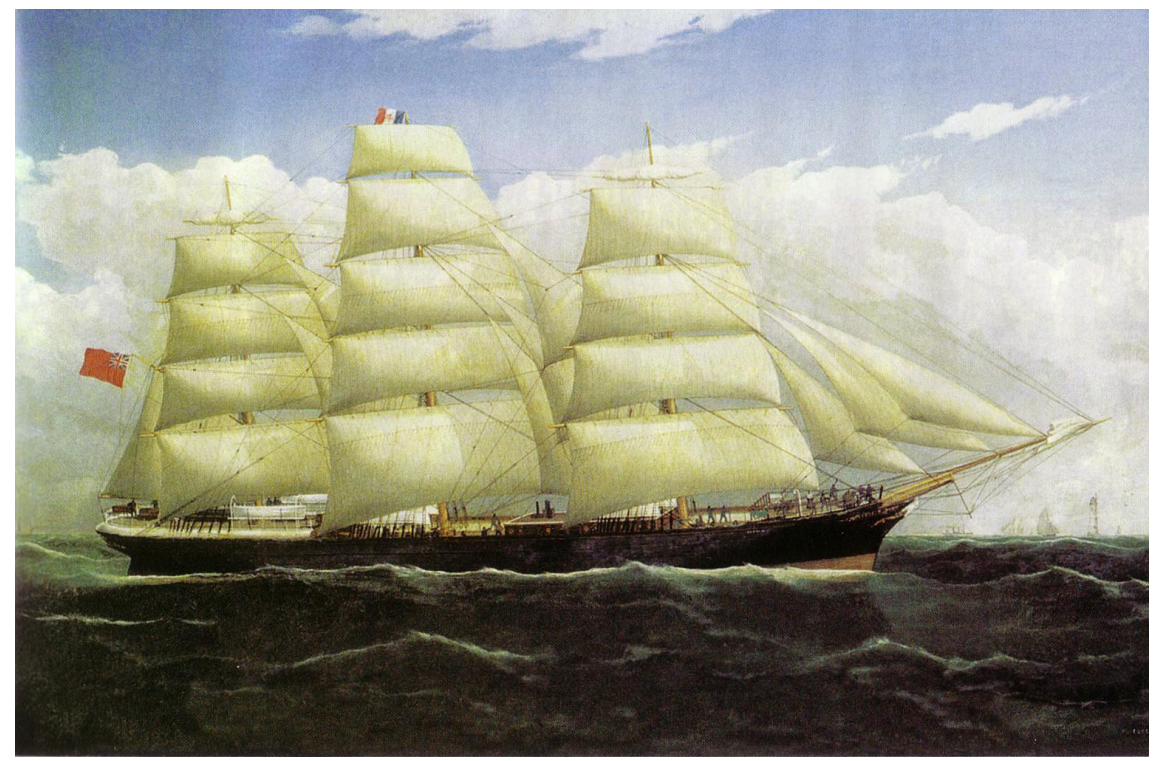

FIGURE 2 The Dunedin's successful voyage in 1882 established the viability of modern refrigerated shipping. Pictured in Shaw, Savill and Albion Line colours, and prior to the fitting of its refrigeration machinery. The ship was lost near Cape Horn in 1890. Painted by Frederick Tudgay in 1875 IMAGE SOURCE: HOCKEN LIBRARY

a limited French success with the Frigorifique in $1877^{6}$ and more so with the Paraguay in 1878. The voyage of the clipper sailing ship Dunedin, which was retrofitted with coal-powered compression refrigeration, from New Zealand to the UK in 1882 was a successful venture, inspiring others to equip vessels with refrigeration.

Thirty years later, in 1912, there were 251 vessels with a total of $44 \mathrm{~m}$ cbf of refrigerated cargo space employed in the meat trades 7 . A common size of a reefer hold was about 180 ooo cbf, although some vessels had about $530000 \mathrm{cbf}$ of refrigerated capacity ${ }^{8}$. Many of the vessels were not specialized reefer ships, but cargo liners with a "half and half" configuration, half frozen and half general cargo, and others merely had some minimal refrigerated locker space. The

6 The cargo was chilled to o degrees and a significant part of the cargo was spoiled. Wijnolst and Wergeland 2009, p. 287.

7 Critchell, J. \& Raymond, J. 1912. A history of the frozen meat trade, an account of the development and present day methods of preparation, transportation, and marketing of frozen and chilled meats, $2^{\text {nd }}$ ed London: Constable \& Company.

8 Dellacasa, A. 1987. Refrigerated transport by sea, Rev. Int. Froid, 10: 349-352. The early period is described on pages $349-35^{\circ}$. 
infrastructure of modern cold storage plants on land was also expanding. A company that eventually managed to make the most of this early refrigerated market is the meat and shipping empire built by the Vesteys, including Blue Star Line (see chapter 8).

\subsection{Bananas}

Long before reefers came into the picture, large volumes of bananas were shipped to the United States. The first recorded banana shipment to New York was by schooner from Cuba in 1804. Irregular, small-scale shipments commenced $^{9}$. They were constantly at the mercy of favourable winds, and spoilage was a major problem. On the other side of the Atlantic, some regular cargo vessels had sporadically carried bananas from the Canary Islands to Europe.

It was the establishment of large-scale plantations in Central America, producing enormous volumes at low economic (albeit not social and environmental) cost, in conjunction with railroads, that created a major market for bananas in the United States in the late 180os. More than 12 million bunches of bananas passed through U.S. ports in 1892 and bananas were considered a "staple article" and they featured in recipe books ${ }^{10}$.

These large-scale plantations were developed by the forerunners of the companies that became United Fruit (now Chiquita) and Standard Fruit (Dole). Close relationships were built up between the companies and political interests in these countries that resulted in major land concessions to the fruit companies. This was a capital-intensive business which resulted in just a few vertically-integrated companies dominating the market. Capital and power in the banana industry tend to concentrate, as Soluri puts it, "in between farms and kitchens". Indeed, legendary "banana men" like Lorenzo Dow Baker, Minor Keith, the Vaccaro brothers, and Samuel Zemurray, all began their carreers as shippers, railroad builders, and wholesalers, not planters ${ }^{11}$.

By the late nineteenth century there was a well-developed infrastructure supplying the United States with bananas. The bananas were brought to market by rail, then steamboat, and then rail again in the United States. The transformation from sail to steam in the shipping industry increased the speed and reliability of the shipments. Spoilage was reduced by improving the cargo's ventilation, vents were added and fans to remove the ethylene gas that bananas produce, expediting the ripening process. These ventilated fruit carriers were a modest improvement over the ordinary cargo vessel. Using the reefer

\footnotetext{
9 Soluri, J. 2005. Banana Cultures, Austin: University of Texas Press, p. 36.

$10 \quad$ Soluri 2005, p. 36-37.

$11 \quad$ Soluri 2005, p. 226.
} 
vessels developed for the meat trade were not an option since bananas are subject to chilling damage and the first reefers could not manage the optimal 12-13 degrees ${ }^{12}$.

The competition between the banana companies was intense and one area of competition was the market's perception of whose bananas were the best. Fruit buyers preferred blemish-free fruit and bunches with as many bananas as possible. To achieve this quality fruit required a high amount of investment in the most uptodate logistics (and later also chemical treatments). For the major banana companies, it was a strategic advantage to develop and invest in refrigerated banana transport.

While the banana majors focused on satisfying the demands of the us market, they also realized that if the quality of maritime transport would improve, the lucrative potential of the overseas, European, market was within reach. British companies were already showing an interest in the transatlantic banana trade and this threatened the existing set-up with United Fruit being dominant and with Standard and Cuyamel as the secondary players.

In the race with bananas across the Atlantic, a British company emerged as the first-mover. The first ship to carry bananas in a reefer hold was the Imperial Direct West India Line's passenger liner Port Morant that shipped bananas along with mail and passengers from Jamaica to Bristol in 1901, about twenty years after the arrival of the frozen meat cargo in London. The cargo arrived in good condition and a regular banana trade with bananas to Europe was inaugurated. To compete with the European shipping lines, in 1903, United Fruit shipped bananas across the Atlantic with the 25 -year old Venus, a river freighter that was retrofitted with primitive refrigeration equipment consisting of ice blocks, animal hair, air ducts and fans ${ }^{13}$. A relationship with Elders \& Fyffes was formed to develop the transatlantic banana trades. Cuyamel (later joining with United Fruit), Standard Fruit (later Dole) and French fruit interests also acquired reefers for long-distance trades. It is estimated that United Fruit controlled as much as $77 \%$ of the world trade in bananas at this time ${ }^{14}$.

The development of suitable reefer transportation in the early 19oos enabled large-scale exports to Europe and the gradual emergence of a global banana market. Public awareness of the health benefits of eating fruit were a

12 Tolerton, N. 2008. Reefer Ships: The Ocean Princesses, Christchurch, NZ: Willsonscott Publishing.

13 Cohen, R. 2012. The Fish that Ate the Whale: The Life and Times of America's Banana King, New York: Random House.

14 Taylor, T. 2003. Evolution of the banana multinationals, in Josling, T.E. and Taylor, T.G. Banana Wars: The Anatomy of a Trade Dispute, California: Institute for International Studies Stanford University, pp. 67-96. 
factor that stimulated demand. The banana also benefited from widespread concerns about germs; the banana, with its peel, was considered a hygienic choice. In time, they became the most important commodity carried by reefers but it remained a luxury commodity in many parts of the world until after the Second World War and in other places not until much later.

\subsection{Fish}

While fishing vessels often return from fishing grounds when the cargo holds are full, another common practice is to offload the cargo to transport vessels that carry the fish to shore. Traders have often sought out fishermen offshore to buy their cargo at a price beneficial to both parties and quickly get it to the markets. With growing populations and more effective means of fishing, particularly the advent of efficient trawling in the beginning of the 190os, fish stocks in rivers and near the coast have gradually been reduced, and fishing has moved farther offshore. Refrigeration technologies are a prerequisite for these long-distance fish trades in the same way as they are to the banana and meat trades described above ${ }^{15}$.

Mechanical freezing of fish kicked off in the late 1800 s at onshore refrigeration sites. The fish was placed on metal plates in contact with a pipe grid where a refrigerant was circulated. Before that, fish was kept cold using natural ice. An early record suggests that in 1797, natural ice was used to preserve fish on imports to the UK. In 1911, the Danish Ottesen patented the process of freezing fish in brine, and gradually ships were equipped with the Ottesen installation and other freezing equipment. The Japanese government subsidized the introduction of these refrigeration technologies at the beginning of the 2oth century ${ }^{16}$.

The experimentation with banana shipments across the Atlantic was interrupted by the First World War. Most of the commercial fleets were tied up in war activities, and during the War, navies as well as merchant fleets were decimated. After the War, trade caught up which caused a demand for shipping. Frozen meat, and rapidly increasing quantities of chilled meat, was transported from

\footnotetext{
15 Dellacasa 1987. Some notes about fish transports are found on pp. 349-350.

16 Nissui. 2012. A History of Hundred Years of Nippon Suisan Kaisha, Ltd., p. 26. Available at: $<$ http://www.nissui.co.jp/english/corporate/10oyearsbook/pdf/10oyearsbook.pdf>.
} 


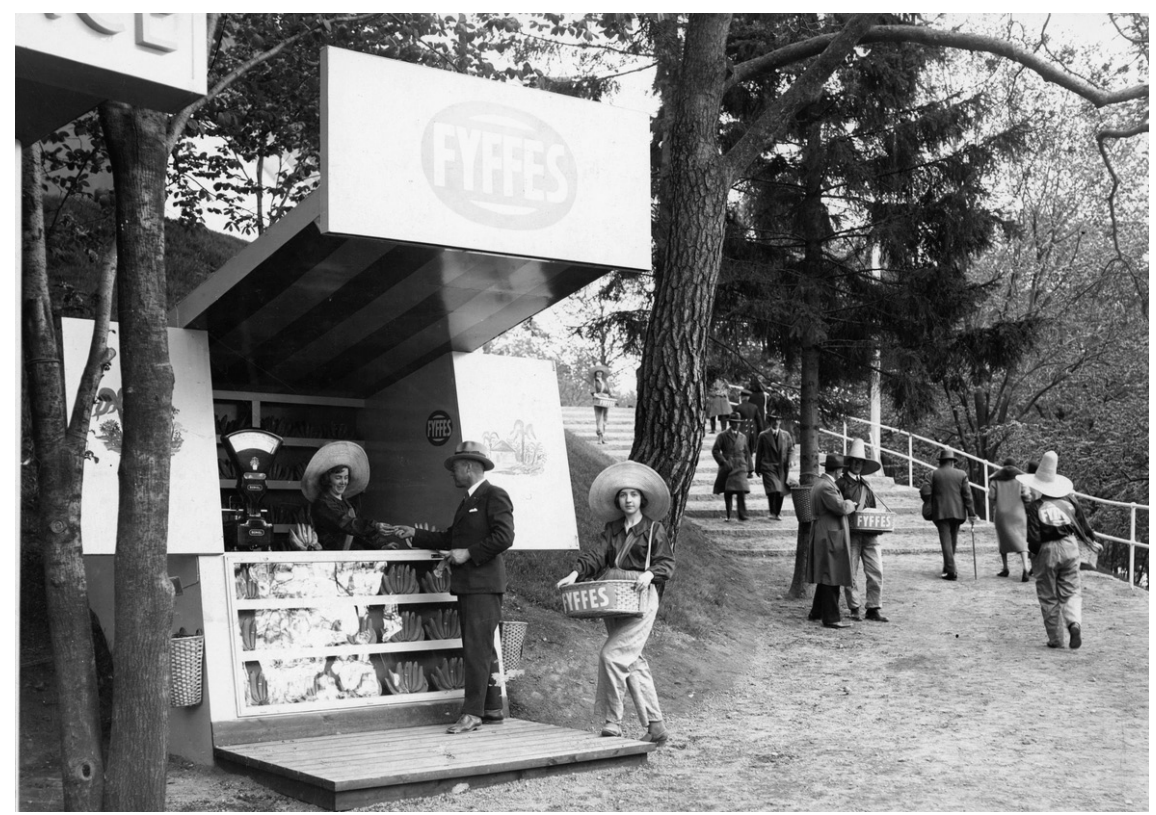

FIGURE 3 Reefer shipping opened up new markets for tropical fruit. Banana marketing by Fyffes at the Stockholm Exhibition in 1930 PHOTO: ARKITEKTUR- OCH DESIGNCENTRUM

the Southern Hemisphere, complemented with dairy products ${ }^{17}$. Moreover, apples and pears, particularly from New Zealand, were carried ${ }^{18}$.

The transatlantic banana trade also grew. New fruit and banana trades were initiated by colonial powers, for example bananas from Italian Somaliland to Italy. The song "Yes! We Have No Bananas" released in 1922 was a major hit. Banana marketing efforts were initiated by the fruit companies in order to teach Europeans to eat bananas and to penetrate the us market even further. By 1929, exports from the banana producing areas of tropical America reached a world-record of 29 million bunches, up dramatically from the 8.4 million of $1912^{19}$.

The banana business became more capital intensive due to the cost of managing the problems caused by two diseases. One of them, Panama Disease, was managed by flooding land areas that were affected while the other, Sigatoka,

17 For a view of Australian exports of meat and dairy products to Britain, see Burley, K. British Shipping and Australia 1920-1939, Massachusetts: Cambridge University Press.

18 Wijnholst \& Wergeland 2009, p. 288.

19 History of the Banana: 1800 to present, Available at: <http://cwh.ucsc.edu/bananas/Site/ Modern\%2oHistory\%2oof\%2othe\%2oBanana.html>. 
was managed by chemical treatment. The increased capitalization created barriers to new entrants in the banana market and favoured the development of the banana majors.

In the 1920s Japanese fishing companies introduced refrigeration onboard vessels and they also built cold stores on shore. The greatest cost for fish was the transport cost and the cost of crushed ice for refrigeration and innovation could be the way out of this situation ${ }^{20}$. In-house on shore ice making facilities were a way for Nissui to lower their costs, rather than relying on a third-party provider. Some fishing companies thus were quite vertically integrated. However, on shore refrigeration equipment helped little when it came to distant water fishing. On-board freezing equipment was necessary. In 1930, new rapid freezing equipment was installed on a handful of Japanese trawlers ${ }^{21}$. As before, the trawlers sometimes went back ashore after filling their cargo holds, but sometimes they transshipped the cargo to a transport vessel, a reefer, which took the fish ashore.

The British refrigerated fleet was the largest in the interwar years, estimated three-quarters of the world fleet in terms of cargo volume in 1923 and twothirds in $1939^{22}$. Reefer tonnage, as with all shipping, was catastrophically affected by the Second World War. The merchant fleet was therefore supplemented by the construction of swiftly constructed "Empire" vessels. These vessels were of many types and included refrigerated cargo liners. The Empire Clarendon and the Empire Abercorn, for example, had refrigerated capacities of over 360 ooo cbf and a service speed of 14.5 knots. They later sailed for Blue Star Line and the New Zealand Shipping Company, which also constructed the important Haparangi class in the late 1940s, consisting of eight large cargo ships with a high capacity for refrigerated and frozen goods.

Refrigerated and frozen cargo during these years continued to be carried in various types of ships. Many were general cargo vessels with a refrigerated capacity that could be as little as refrigerated lockers. These were liner trades and were usually regulated by the shipping conferences. There were also dedicated reefers, particularly for the banana trade, but even these frequently carried passengers. Ventilated fruit carriers and general cargo vessels continued to carry fruit, particularly for shorter distances, for example from the Caribbean to USA and in the Mediterranean and Baltic Seas. Lauritzen and Saléns started to operate in these regional trades but had the ambition to service the transatlantic reefer trades.

\footnotetext{
$20 \quad$ Nissui 2012, p. 63.

21 Nissui 2012, p. 77.

22 Wijnolst and Wergeland 2009, p. 288.
} 
The post-war refrigerated shipping market was constrained in a number of ways and its growth was initially modest. Many important markets for perishables were in ruins, particularly in Europe and East Asia. Following the General Agreement on Tariffs and Trades, the signatory countries lowered tariffs which contributed to the growth of world trade. This combined with postwar reconstruction contributed to the start of a period of economic prosperity in the 195 os for most industrial countries, which increased the trade of various goods (oil, ore, grain, etc). This affected the shipping industry positively, also increasing the demand for refrigerated tonnage. It wasn't long before bananas and other imported fruit were a part ordinary people's lives in prosperous regions. The demand side was slowly recovering. In 1961, the world reefer trade was about 18 million tons, while at the end of the same decade it had increased to around 25 million (see Graph 5).

But during the 1950s and 196os, the shipping industry also underwent a transformation from the structure of cargo liners, passenger liners and tramp ships that had existed since the early 19oos. In this period, the cargo liner companies were undergoing a revolution as the modern intermodal container began to make serious headway ${ }^{23}$. In 1969, the first purposebuilt reefer container ships were introduced by OCL and $\mathrm{ACT}^{24}$. This posed significant demands on new terminals and new cargo handling equipment and skills related to general cargo. For the reefer cargoes, the challenges were even bigger. Early refrigerated containerization was based upon the idea that the ship had central refrigerated units and the cold air was ducted to what are usually referred to as porthole containers. However, early refrigerated containerization was not a success and this created great opportunities for independent reefer operators. This coincided with increased consumer expectations for off-season produce, for example, apples in the supermarket year-round. Also, the partly refrigerated passenger liners were a dying breed and the passenger traffic they had carried had dwindled as the jet-era of mass tourism had begun.

The general trend was that the general cargo was containerized, the passenger traffic and mail gradually shifted to airlines, and that a number of specialized shipping segments were emerging ${ }^{25}$. Specialized bulk shipping vessels

23 For more background on containers see Levinson, M. 2006. The Box: How the shipping container made the world smaller and the world economy bigger, Princeton: Princeton University Press, and, Donovan, A. and Bonney, J. 2006. The box that changed the world, Ubm Global trade. See also Klose, A. 2015. The Container Principle, Massachussetts: MIT Press.

24 Wijnolst and Wergeland 2009, p. 288.

25 Stopford 2009, p. 36. 
such as oil tankers had existed but developed significantly during this period - their size grew exponentially, given that the transport cost per unit decreases with increasing ship size. A similar but not as pronounced tendency can, as we will see, be witnessed in the case of reefers.

Perhaps the timing of this transformation of the shipping industry was not unexpected. Tonnage losses, as previously mentioned, had been enormous during the Second World War, and the fleet that survived was soon obsolete. This presented opportunities, however, to renew the transport system within all shipping segments. Technological advances had been strong within fields such as refrigeration and automation, and such advances trickled down into the maritime reefer industry. The 1950s and 196os therefore turned out to be a period of innovation and it enabled the subsequent boom in perishables transport in the decades that followed. Improved refrigeration reduced spoilage. Automation and more reliable machinery reduced maintenance and crewing requirements. Some vessels had unmanned engine rooms. The refrigeration systems were also improved and the development of electronics made systems of automatic temperature control possible. Modern vessels could manage a wide range of temperatures, handling many types of cargo with different atmospheres in its separate gas-tight compartments. Improved cargo handling and faster vessels reduced turnaround times drastically. Speed was a major factor due to the precarious nature of the cargo. While the speed of reefer vessels before the Second World War were often around 15-16 knots, this increased and for example Lauritzen's Italian Reefer class boasted a speed of 22 knots in 1968 (see Graph 4).

Apart from the general developments in world trade and the shipping industries, the reefer industry was impacted by developments in their respective cargo categories. Regarding bananas, the Panama Disease all but wiped out the Gros Michel banana in the 1950s, and this led producers to develop a diseaseresistant variety, the Cavendish ${ }^{26}$. However, the Cavendish was more fragile and easily bruised during handling. To solve this problem, the banana companies started to pack them in boxes prior to shipment. The increased operating cost associated with boxing and disease control contributed to economic problems for both United Fruit and Dole. Both companies subsequently reduced their own fleets in order to free up capital. Their shipping needs were increasingly supplied by independent reefer operators like Saléns and Lauritzen.

26 The Cavendish is the main variety internationally traded today. Plantains used as food in India and many parts of Africa actually constitute the largest volume of bananas that are grown. The Cavendish banana is presently being ravaged by a different strain of Panama disease in many parts of the world. A replacement is being sought and efforts are also being made to genetically engineer a resistant variety. 


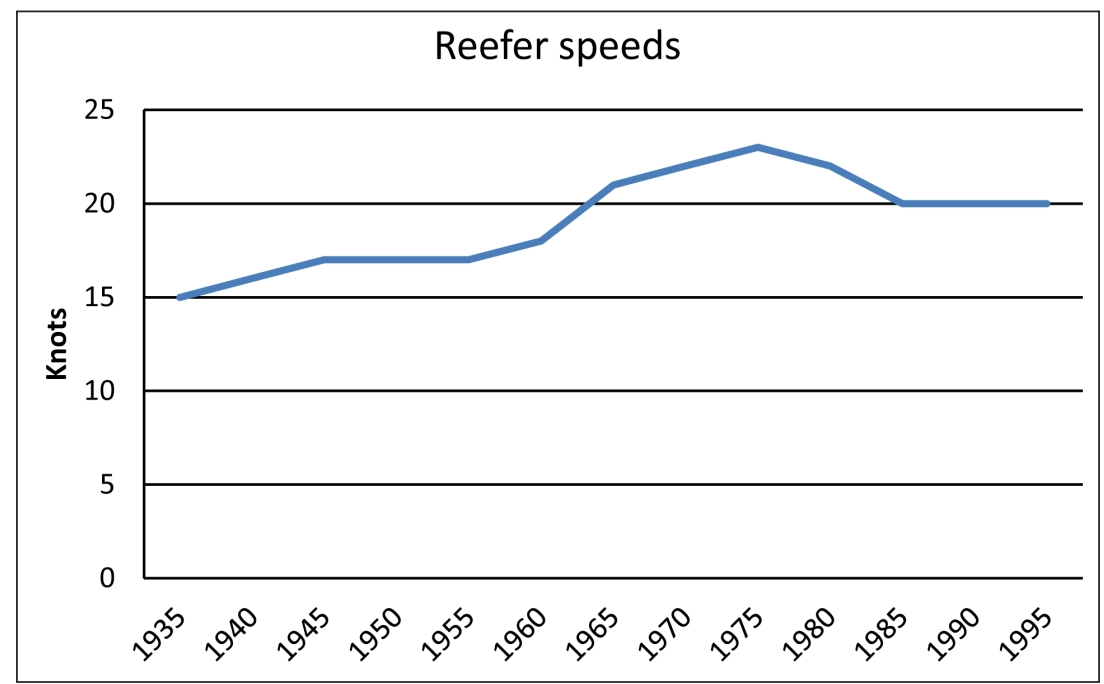

GRAPH 4 Reefer speeds. The graph gives the typical rated speed for newly constructed large reefers. The lower speeds after the late 1970 s is due to the prioritisation of fuel efficiency following the oil crises.

Note: Created on the base of indicative speeds of large reefer newbuildings from 1935 to 1995 from Tolerton 2008.

Regarding fish, fishing fleets continued to search further afield and increased the necessity of transshipment. A new development within the fishing industry was the growth of the international fish trade and this provided a new business where fish was transported from port to port. For example, Gustaf Erikson's 1957 newbuilding Fiskö went directly from the shipyard to load fish in Reykjavik, Iceland ${ }^{27}$.

Similar to the unitization of the liner companies, unitization was also discussed within the reefer trades. The cargo on reefer vessels were of varying kinds, sizes and shapes, and given the inefficiency of handling such cargo, the reefer industry started to consider the unitization of cargo. Although some experiments had been made with container technology, the major breakthrough was palletisation. Palletisation began in earnest and Saléns started an integrated pallet service for Sunkist in 1969 .

27 Malmberg, T. and Hag, E. 2013. Kalla Systrar från Åland på världens alla hav, Mariehamn: Stiftelsen Hilda och Gustaf Eriksons samt Gustaf Adolf Eriksons Understödsfond, p. 9091. 
The 1970s promised to be a golden era for the independent reefer operators. The liner industry was struggling with refrigeration, while the demand for perishables was increasing year by year. New, modern ships, like Salén's Snow class and Blue Star Line's A-class, were ordered, and new entrants were eyeing the reefer segment. The liner conferences' importance diminished during these decades $^{28}$. This presented more cargo opportunities for the independent reefer operators.

However, the oil crises of the 1970s drastically raised operating costs, and combined with oversupply of tonnage, translated into weak profitability. Given the increased cost of bunker fuel the operational speed of newbuilt reefers stagnated. While the focus had been on pushing up the speed for each successive generation of reefer vessels in the 1950s and 196os, the oil crises of the 1970 stopped this development. This is not to say that reefers were slow ships - a typical reefer speed stabilized at 20 knots. However, the rise of oil prices led to more concern with bunker consumption than in previous periods (see Graph 4).

Due to the oil crises, there was an abrupt end of the boom in the shipping market that had been ongoing since the 1950s. This cascaded into the shipbuilding market which was of central concern to the governments of shipbuilding nations ${ }^{29}$. European governments subsidised national shipbuilding in the 1970 s and 1980s to remain competitive and avoid the unemployment that would result if the shipyards were closed. Many shipping companies, including the reefer segment, seized the opportunity to build vessels, but in general the verdict is that this resulted in an oversupply of tonnage in all ship categories. State subsidised shipbuilding was threatened by the Gibbons Bill in the Us, which would have prohibited subsidized vessels from entering ports in the Us $^{30}$. Subsequently, shipbuilding became more competitive and most reefers in later decades were built in East Asia.

Still, the demand for transport of refrigerated products grew. Graph 5 shows the development of the international trade in refrigerated products. In the 1970 s and 1980s, the trade of refrigerated products increased. In 1970 it was around 25 million tonnes while in 1990 it had risen to almost 50 million tonnes.

\footnotetext{
28 Stopford 2009, Chapter 13.

29 Todd, D. 1991. Industrial Dislocation: The Case of Global Shipbuilding, London and New York: Routledge.

30 Waters, R.C. 1993. Federal Regulations and the Competitiveness of U.S. Liner Ship Operators, Transportation Journal, 33: 53-58.
} 


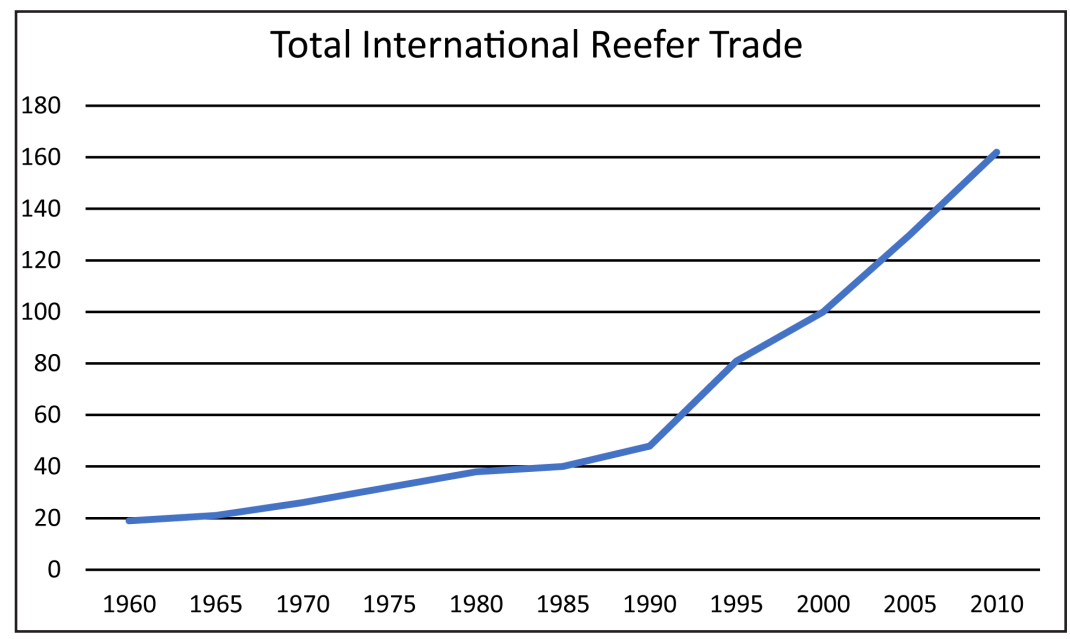

GRAPH 5 Total international reefer trade (not just seaborne)

Note: Modified from: Arduino, G. and Parola, F. 2010. Cold Chain in the Shipping Industry: Bulk versus Container in the Banana Trade, 12th World Conference on Transport Research, July 11-15, 2010 - Lisbon, Portugal. Figures are in turn drawn from Nomadic ASA and Drewry with authors' elaboration.

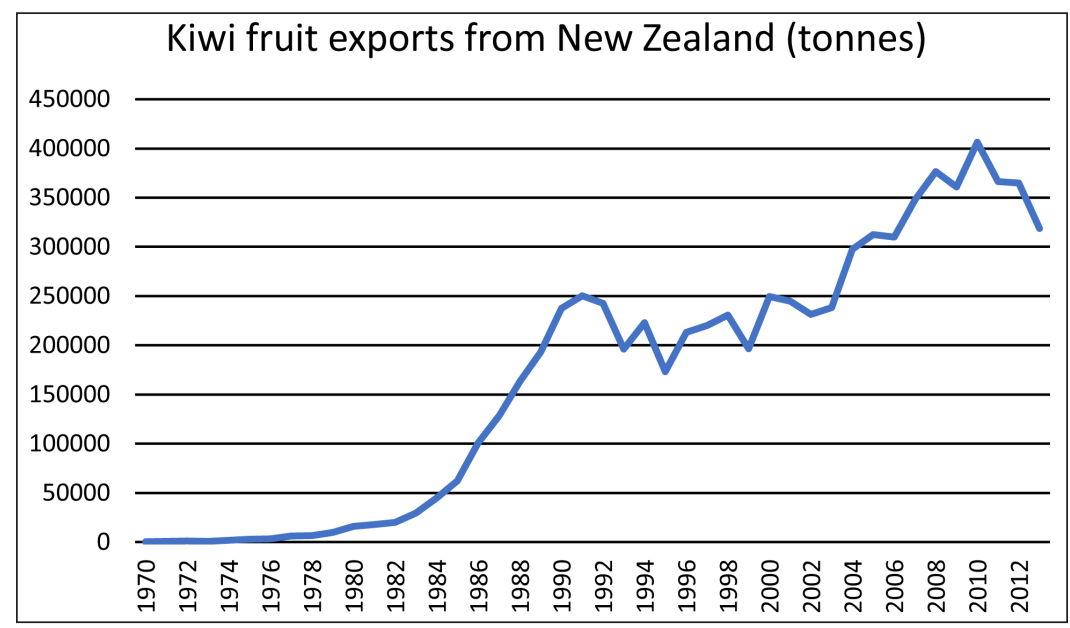

GRAPH 6 Kiwi fruit exports from New Zealand (tonnes)

Note: (c) FAO, Food and Agriculture Organization of the United Nations, <http://www.fao.org/faostat/en/\#data/TP>. 


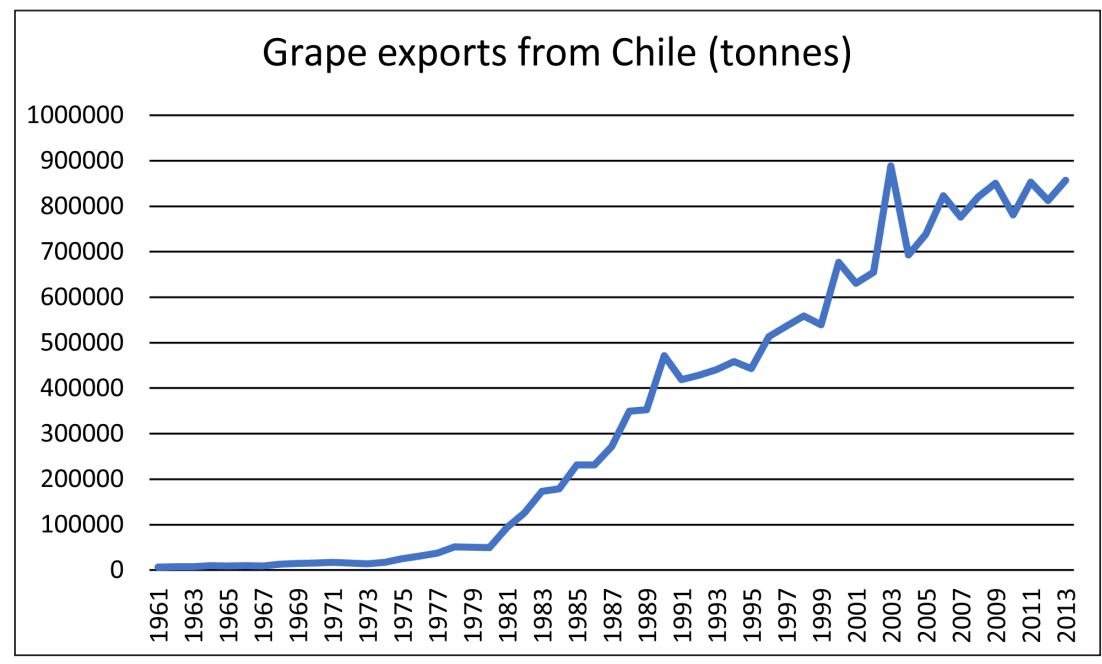

GRAPH 7 Grape exports from Chile (tonnes)

Note: (c) FAO, Food and Agriculture Organization of the United Nations, <http://www.fao.org/faostat/en/\#data/TP>.

Exported volumes of grapes from Chile and kiwifruit from New Zealand grew rapidly during the 1980 s (see Graphs $6-7$ ). The ship supply increased accordingly. From a capacity of $250 \mathrm{~m} \mathrm{cbf}$ in 1980 it increased to about $325 \mathrm{~m}$ in 1990 (see Graph 8).

The palletisation process which gained traction in the 196os, continued into the 1970 s and 1980s. As a result, new pallet-friendly reefers were built with optimised deck configurations. The idea was to maximise the number of pallets that a ship could carry. The height of each deck was designed to cater for fully stacked pallets and the ships were also built "squarer" to avoid unutilized cargo space in the holds. This was also done in order to increase speedy deliveries even though the ships were not sailing faster. The old breakbulk reefers continued to see service for many years as backup tonnage and for service in the fish trades. Palletisation also brought with it a change in cargo handling equipment. From derricks having been the major cargo handling equipment on reefer vessels, newer vessels increasingly came with cranes which could load multi-pallet cargo holders. 


\section{Palletisation and Pallet Heights}

The first reefers built for palletised goods were designed for pallets loaded to a height of approximately 1.9 metres, for example Salén's Snow vessels. This equated to the height of seven boxes of fruit and also allowed for a small amount of airspace above the boxes, for the proper circulation of cold air. During the 1970s, however, the Confederation of Importers and Marketing Organisations in Europe of Fresh Fruits and Vegetables (сімо) lobbied for this height to be increased. More goods per pallet would equate to reduced transportation and handling costs. The major fruit companies resisted this initially. On the one hand, the cartons that contained the fruit needed to be robust enough to handle the additional weight but, more significantly, the higher pallets wouldn't fit into the existing cargo holds. However, the oil crises made the existing fleets expensive to sail and thus there was an interest in obtaining new bunker-efficient vessels that could then also meet the new agreed up standard pallet height of approximately $2.1 \mathrm{~m}$ ( 8 boxes high). The new vessels were therefore built with a deck height of $2.2 \mathrm{~m}$, once again allowing sufficient airspace above the cargo to allow the cold air to circulate. Older vessels were usually sold and considered obsolete by the major operators, at least for some of the fruit trades that attracted better freight rates. In some cases, for example the Snow vessels, they were converted by lowering the gratings on which the pallets rested and installing thinner insulation in the ceiling. While palletisation was ongoing, less modern vessels were still used by operators as a reserve fleet, which was laid up except for in high markets, or as ships that could serve fishing fleets.

During the 1990s and 2000s, the world underwent a process of privatization and liberalization of markets. Many fruit exporting countries had national export boards which acquired transport capacity. Often the exported quantities were high because of the association of many independent growers, leading to the potential to fill up an entire specialized reefer. However, many of these export boards have been dissolved, leading to more fragmented quantities which could be carried by liner vessels. On the demand side, there has been a growing number of large players, such as supermarket chains. Walmart is a good example. With considerable market control, major supermarket chains have a complex supply chain and meticulously control the supply of goods. It has 
been argued that such players prefer the continuous delivery of fruit, meat and fish rather than large but less-frequent bulk-deliveries supplied by specialized reefers.

The collapse of the Soviet Union and related political change opened up new markets for reefer operators. There was a demand for imported fruit in the post-Soviet and Eastern European countries, a demand that was previously inadequately supplied. The opening up of these markets also led to the entry of new players and ships on the market. Eastern Europe has grown in importance while Western Europe has declined in the first decade of the $200 \mathrm{~s}^{31}$.

On the demand side, the period after 1990 witnessed a veritable boom in the trade of refrigerated products. From the traded volume of $50 \mathrm{~m}$ tonnes in 1990, in 2010 the traded volume amounted to almost 170m tonnes (see Graph 8). Interestingly, this market boom coincided with a decline of specialized reefer tonnage. From the peak of about $380 \mathrm{~m}$ cbf of specialized reefer tonnage in 1994, the capacity has declined to about $230 \mathrm{~m}$ cbf in 2013, a bit lower than it was in 1980 (see Graph 8). The number of newbuildings since the 199os has decreased to the point that at the end of 2016 there were about 16 newbuildings in the orderbooks ranging between 120000 and $650000 \mathrm{cbf}^{32}$. Scrapping on the other hand has been on the increase, particularly since 2008 resulting in a dwindling world reefer fleet (see Graph 8).

At the high point for the independent reefer operators, in 1993, about $35 \mathrm{~m}$ tonnes of cargo was transported by ship ${ }^{33}$. Graph 9 shows the relative importance of the commodities carried by reefers. Bananas have occupied an exceptional position in the transport of refrigerated cargo.

A third of the maritime reefer cargo was carried in containers ${ }^{34}$, where the dominant cargo was meat ( $40 \%)$ followed by bananas $(20 \%)$, dairy $(13 \%)$ and other goods ${ }^{35}$. In 1998, $45 \mathrm{~m}$ tonnes was transported by ship ${ }^{36} .40 \%$ of this was bananas, something which has varied little since the 1980s. In 1997, when the capacity of the container lines overtook that of specialized reefers, the container lines still only conveyed $42 \%$ of the cargo. ${ }^{37}$ In 1980 , full reefers of more than 100 ooo cbf provided $65 \%$ of global capacity, but in 1997 this had fallen to

$31 \quad$ Damas, P. Reefer Market Overview, Drewry, Conference presentation, Long Beach 5 March 2013. "Healthy Orderbook for Reefers". The Maritime Executive 29 January 2017. <http://maritime-executive.com/editorials/healthy-orderbook-for-reefers>. "Kylsjöfart", Svensk Sjöfarts Tidning 1993/50, p. 72. "Kylsjöfart", Svensk Sjöfarts Tidning 1993/50, p. 72. "Kylsjöfart”, Svensk Sjöfarts Tidning 1993/50, p. 72. "Kylsjöfart", Svensk Sjöfarts Tidning 2000/50, p. 55 . Branch, A. 1998. Maritime Economics: Management and Marketing, New York: Routledge, p. 101. 


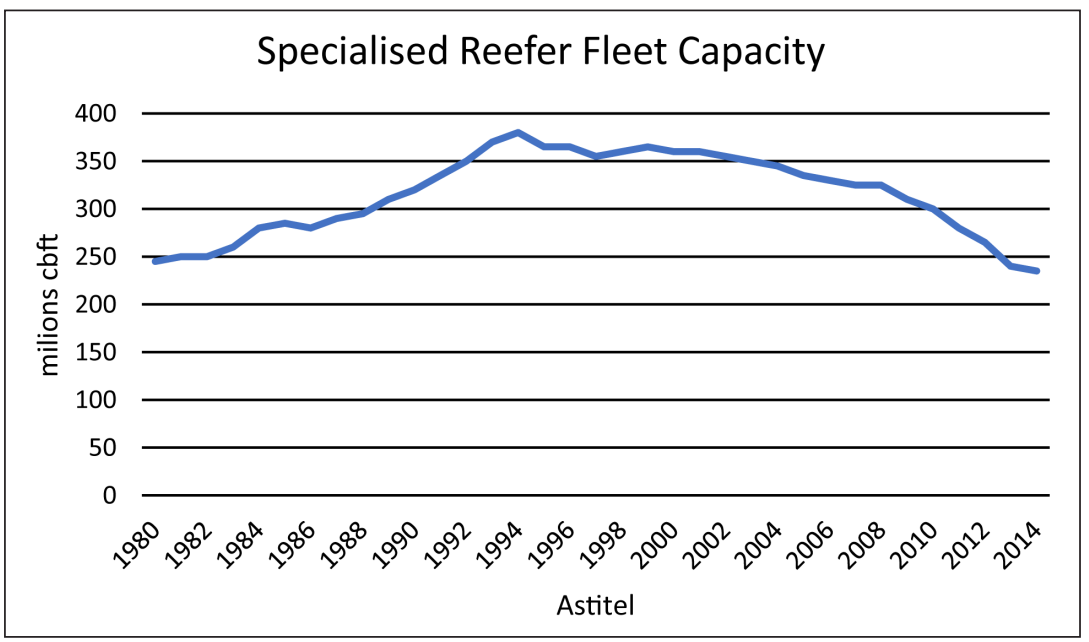

GRAPH 8 Specialised reefer fleet capacity

Note: Data supplied by Seatrade.

$47.2 \%$ under deck and 2.8 over deck. ${ }^{38}$ In 2019 , the share of the container lines is expected to reach $83 \%{ }^{39}$

Refrigerated containers began to make serious inroads into the refrigerated shipping market in the 199os. Integrated containers became the preferred technological choice because of their flexibility; they only required a suitable power source ${ }^{40}$. The growth of the refrigerated container business from the South to the North is also partly a result of the container lines desire to find backhaul cargo for their business. In other words, what was the main business for reefers, was interesting backhaul cargo for the container lines. The container lines were therefore willing to accept fruit in refrigerated containers at low rates in the same way that reefer operators were willing to frequently transport cargo at low rates on their backhaul routes.

As can be seen from Graph 10, from the early 1990s, reefer container capacity on ships has increased rapidly. It is now worth remembering that we are essentially dealing with a re-entry of liner operators into the reefer cargo, which was enabled by the technological development of the reefer container. Reefer containers gradually became more reliable, could control the temperature more accurately, and also developed systems for controlled atmosphere

\footnotetext{
$38 \quad$ Branch 1998, chapter 4.

39 "A Perspective on Refrigerated Container Trade Growth". GEP Mind. <https://www.gep. $\mathrm{com} / \mathrm{mind} / \mathrm{blog} /$ perspective-refrigerated-container-trade-growth>.

40 See also Wijnolst and Wergeland 2009, pp. 287-290.
} 


\section{Reefer Cargo by volume 1993}

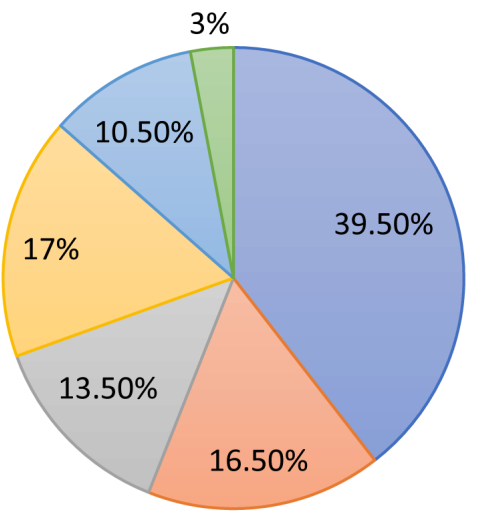

Bananas $\square$ Citrus $\square$ Other fruit $\square$ Meat $\square$ Fish $\square$ Other

GRAPH 9 Reefer cargo by volume (1993)

Note: "Kylsjöfart", Svensk Sjöfarts Tidning 1993/50, p. 72.

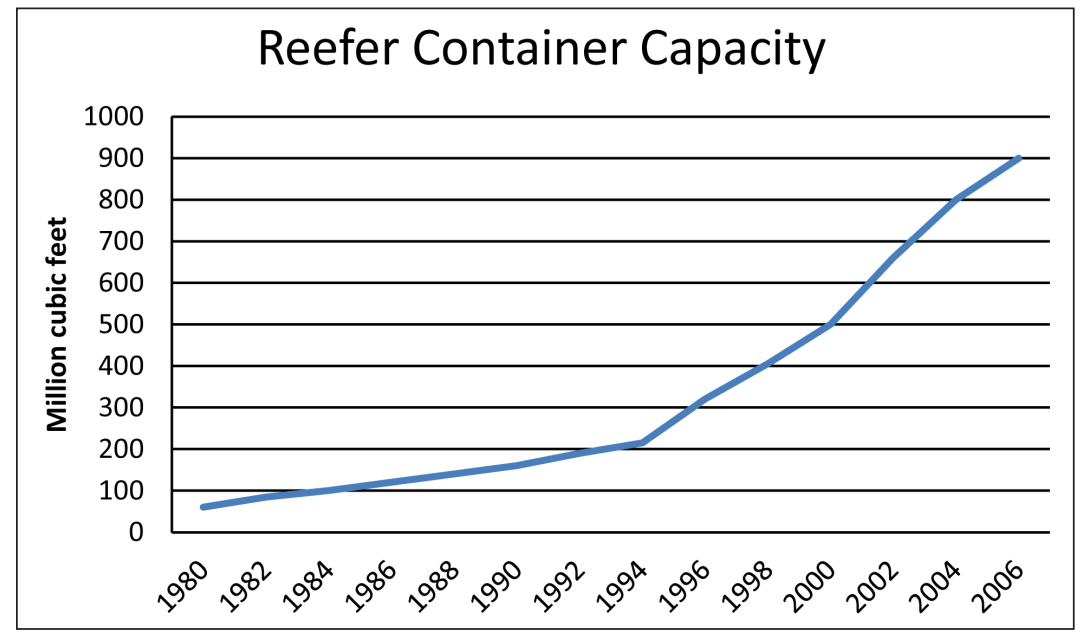

GRAPH 10 Reefer container capacity

Note: Note that this graph shows capacity, not what was actually used. Arduino and Parola 2010. Figures are in turn drawn from Drewry and Containerisation International. 
necessary to transport fruit. Due to the increased containerization, cranes on specialized reefer vessels are designed to carry heavier loads. A recent paper by Thanapolou ${ }^{41}$ discusses the specialized reefer market and shows that the bulk reefer market has reached the declining end of the product life cycle. Another recent paper by Arduino concurs with Thanapoulou's analysis and explains that the costs of transporting a pallet in a reefer container, vs. a pallet in a specialized reefer vessel is a major reason for this shift ${ }^{42}$.

This re-entry of container lines into the reefer segment led to increased competitiveness and also a need for specialized reefer operators to take strategic action. While the strategies of the various operators will be covered in the main bulk of the text, we can here say that regarding ships, more ships moved into the hybrid type, where the under-deck palletised cargo was complemented with reefer containers on the weather deck. Some operators have built reefer container vessels, which are small container vessels where the entire cargo can be refrigerated. There has also been development towards side-loading vessels, which are palletised reefers without hatches, making them insensitive to the weather. Furthermore, in the 2010s, the development of a reefer ro-ro ship was discussed, where pallets could be carried on cassettes, similarly to how forest companies transport their outgoing cargo.

Summary

The independent reefer operators and the reefer industry in general have been affected by various economic and political events over the decades. Partly as a result of these global trends, the reefer market has had its ups and downs over the years and one representation of this is to look at the development of market rates. Graph 11 charts 12-month nominal timecharter rates. One observation that we can make is that if we allowed for inflation then it should be apparent that rates have decreased in real terms. The good years and the bad years have had various effects and different actors have followed different strategies as we shall see in the chapters below. However, it is also important to note that these market rates are also influenced by the individual actors, their willingness or unwillingness to invest in tonnage, increase operational efficiency, negotiate rates with shippers, and so on. This is one reason why one cannot

41 Thanapolou, H. 2011. Bulk reefer market economics in a product life cycle perspective, Maritime Policy \& Management, 39: 281-296.

42 Arduino, G., Murillo, D.C and Parola, F. 2013. Refrigerated container versus bulk: evidence from the banana cold chain, Maritime Policy \& Management, 42: 1-18. p. 2. 


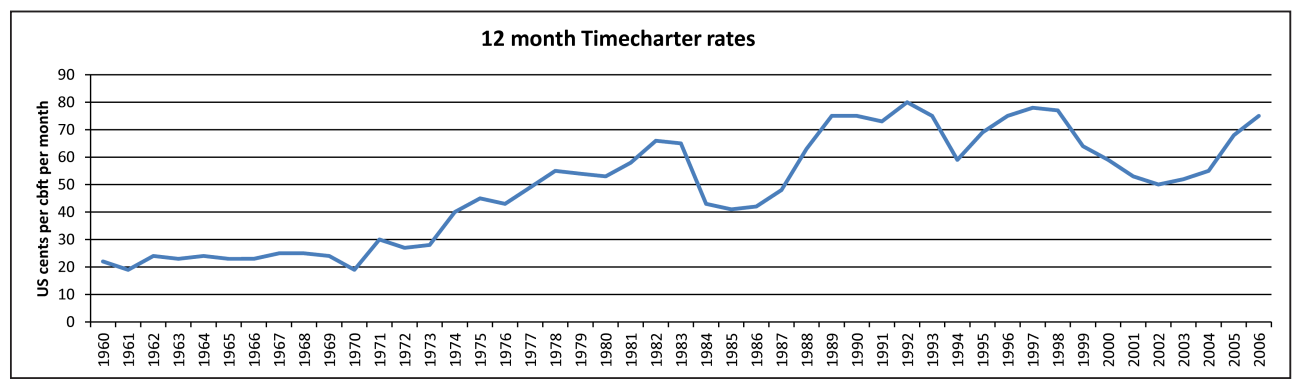

GRAPH 1112 months timecharter rates

Note: The graph is created on the base of data from "Kylsjöfart", Svensk Sjöfarts Tidning 1993/5o, p. 74. Cool Facts 1989, p. 6, Cool Facts 97-98, p. 4 (data supplied by A/S Klaveness Chartering, Oslo), Cool Facts 1999-200o p. 6 and Star Reefers Annual Reports. The data in the graph is derived from multiple sources which in turn derive their figures by different methods, it should be regarded as indicative rather than precise.

neglect taking an individual perspective of the independent reefer operators, apart from seeing them as a collective phenomenon.

Returning to the graph, the stability in the 1960 s can be explained by the continued regulation of shipping conferences. The rise in rates during the $1970 \mathrm{~s}$ was a result of several factors, a modest rise in refrigerated trade is one of them. An important factor is the scrapping of liner tonnage with reefer capacity. This created a "gap" which the reefer industry successfully made the most of and many new vessels were built. The effect of the global recession following the oil crises impacted heavily on the reefer industy in the mid 1980s and this contributed to a decline in market rates. Some excellent years in the late 1980 s fuelled ambitious newbuilding programmes which in conjunction with the competition from the container lines created an overcapacity which contributed to a decline in the late 199os. This led to a gradual scrapping of the specialized reefer fleet and a sharp decline in reefer newbuildings, which has continued until the present day. 
PART 2

The Independent Reefer Operators 
In this part we describe the protagonists of our study - the independent reefer operators. Some of them began their operations as independents while others diversified from being a liner company or a shipper. 